\title{
OPTIMALISASI PERAN STRATEGIS AMIL ZAKAT DALAM PERSPEKTIF HUKUM ISLAM DAN HUKUM POSITIF INDONESIA*
}

\author{
Ahmad Mukri Aji ${ }^{1}$ \\ Permalink: https://www.academia.edu/9964076
}

\begin{abstract}
Optimizing the Strategic Role of Zakat in the Perspective of Islamic Law and the Positive Law in Indonesia. Zakat is a part of the religious pillars that must be enforced. It is an important component that has a vertical and horizontal dimension of worship in order to maintain the benefit of human life. Zakat has a particularly significant role in maintaining the stability of the economy. Hence require good management, it is recommended in the Qur'an as Amilin. The Amilin is expected to mediate professionally and seriously to take care of, manage, collect, and distribute zakat. In this paper, zakat is expected to play an optimal role in order to empower the existing charity. So it can contribute to the welfare of mankind.
\end{abstract}

Keywords: Optimizing, Strategic Role, The Amil of Zakat

\begin{abstract}
Abstrak: Optimalisasi Peran Strategis Amil Zakat Dalam Perspektif Hukum Islam dan Hukum Positif Indonesia. Zakat merupakan bagian dari pilar agama yang harus ditegakkan. Ia merupakan komponen penting yang memiliki dimensi ibadah vertikal dan horizontal guna menjaga kemaslahatan hidup manusia. Zakat memiliki peran yang signifikan terutama dalam menjaga kestabilan perekonomian. Karenanya diperlukan manajemen pengelolaan yang baik, yang dalam hal ini direkomendasikan Alquran dengan sebutan amilin. Pihak ini diharapkan mampu memediasi secara profesional dan serius untuk mengurus, memanage, mengumpulkan, dan mendistribusikan zakat. Dalam tulisan ini, amil zakat diharapkan berperan secara optimal guna memberdayakan zakat yang ada. Sehingga dapat memberikan sumbangsih kesejahteraan bagi umat manusia.
\end{abstract}

Kata kunci: Optimalisasi, Peran Strategis, Amil Zakat

* Diterima tanggal naskah diterima: 07 Maret 2014, direvisi: 30 April 2014, disetujui untuk terbit: 10 Juni 2014.

${ }^{1}$ Fakultas Syariah dan Hukum UIN Jakarta. Jl. Ir. H. Juanda No. 95 Ciputat Jakarta. E-mail: mukriaji@yahoo.com 


\section{Pendahuluan}

Reformasi Risalah Islamiyyah yang telah dibawa oleh Rasulullah Muhammad Saw 15 abad yang lalu telah terimplementasi dalam bentuk pesanpesan Ilahiyyah yang termaktub dalam teks ayat Alquran al-Karim dan telah teraktualisasi pada sebuah bangunan kokoh ajaran agama Islam (arkan ad-din), yaitu sehat berakidah dan bertauhid (sehat ruhaniah), sehat bersyariah, dan sehat berakhlak. ${ }^{2}$

Pertama, Sehat berakidah dan bertauhid (sehat ruhaniah), yang terisi dan terpatri pada hati dan sanubari setiap insan hamba-Nya merupakan sikap mental yang selalu dilandasi dan termotifasi dengan semangat kalimatut-tauhid, La ilaha illallah (Tidak ada Tuhan yang wajib disembah melainkan Allah) akan mengusir dan mengikis berbagai macam virus ruhaniyyah, semacam: virus alkibr wat-takabbur dengan terjadinya arogansi dan kesombongan intelektual, virus al-Ananiyyah (egoistik terhadap dirinya yang paling pandai dan paling benar), dan yang sangat berbahaya adalah virus kekafiran (al-kufr), serta virus kemusyrikan (asy-syirk), yang telah menjadikan berbagai fasilitas yang dimilikinya adalah segala-galanya. Sehingga dalam situasi, kondisi dan posisi apapun seorang hamba Allah yang saleh akan selalu menggantungkan berbagai problematika kehidupannya kepada Yang Maha Kaya, Yang Maha Berkuasa, dan 97 Maha lainnya.

Curhat Vertikal selalu dilakukan dengan berbagai media ibadah, baik ibadah mahdhah kepada Allah SWT misalnya: shalat lima waktu, shalat-shalat sunnah, puasa Ramadhan dan puasa-puasa sunat, haji dan umrah, tilawah alQur'an, zikir dan doa, serta ta'lim, maupun ibadah sosial (ibadah ghaeru mahdhah) yang diberikan untuk kepentingan kebutuhan hidup diri pribadi, keluarga, kalangan dhu'afa, anak-anak yatama, fuqara, dan masakin, seperti: zakat, infak, shadaqah, wakaf, dan berbagai bantuan sosial lainnya.

Kedua, Sehat Bersyariah. Sehat bersyariah merupakan potensi dan kemampuan seorang hamba Allah yang tulus dan penuh kesadaran untuk menjalankan aturan-aturan, norma-norma hukum syariah yang akan mengawal seseorang untuk melakukan berbagai aktifitas dan perbuatan, baik yang berkait dengan persoalan ibadat maupun mu amalat. Dimulai dari masa balignya, sejak bangun tidur sampai tidur kembali (siklus 24 jam) dan seterusnya sampai hayatnya terpisah dari jasadnya dalam posisi disayangi dan dimuliakan, serta diridhai oleh Yang Maha Pengasih lagi Maha Penyayang. Sehat bersyariah ini teraktualisasi dalam bentuk bangunan Rukun Islam yang lima: 1). Mengucapkan dua kalimah syahadah. 2). Mendirikan shalat, 3). Mengeluarkan zakat, 4). Melaksanakan ibadah shaum Ramadhan, dan 5). Menunaikan ibadah haji ke Baitullah al-Haram.

Ketiga, Sehat Berakhlak. Upaya untuk menuju sehat berakidah dan sehat bersyariah mesti diisi dan dihiasi oleh sehat moral (mental) untuk melakukan berbagai aktifitas yang selalu dilandasi oleh semangat Lillahita'ala.

${ }^{2}$ Alî Ahmad Al-Jurjânî, Hikmah at-Tasyrî̀wa Falsafatuhû, (Singapura : al-Haramain, t.th.), h. 44. Lihat pula: Ahmad Muhammad al-Hasri, Tafsîr Âyât Al-Ahkâm (Beirut :Dâr alQalam, t.th),h.23 
Sehingga sentuhan semua aktifitas hamba-Nya, teraktualisasi dalam bentuk gagasan dan pemikiran yang sehat, ucapan yang santun dan lembut, tulus ikhlas dan penuh sadar hukum, dengan tidak menzalimi dan menyakiti hati siapapun, terbangun semangat saling sayang menyayangi, cinta menyintai, saling asah, asih, asuh, serta dapat dirasakan dampak positifnya baik untuk dirinya, masyarakat lingkungannya, maupun bangsa dan negaranya. ${ }^{3}$

Sikap hamba Allah yang selalu konsisten selalu berpegang teguh kepada komitmen pernyataan dua kalimah syahadat yang melandasi semangat ibadah yang dilakukan, baik shalat lima waktu yang merupakan bentuk ibadah vertikal yang bernuansa sosial jika dilakukan secara berjamaah, puasa Ramadan juga merupakan ibadah vertikal yang bernuansa sosial dengan selalu melaksanakan berbagai aktifitas berjamaah, demikian juga ibadah haji merupakan ibadah vertikal yang dilakukan setahun sekali dalam seumur hidup. Akan tetapi, ibadah zakat baik zakat fitrah maupun zakat mal merupakan ibadah vertikal sekaligus juga sebagai ibadah harta benda dan ibadah sosial (ibadat maliyah wa alIjtima 'iyyah) yang mewajibkan para muzakki mengeluarkan rezki yang diperolehnya. Kewajiban berupa beras atau yang senilai 3 1/4 liter. Demikian pula, ketika telah cukup nishabnya dan haul atau telah tiba masa panen, maka terkena kewajiban membayar zakat mal.

Dalam perspektif hukum Islam, pelaksanaan penghitungan, penyerahan dan pendistribusiannya dapat langsung dilakukan oleh muzakki kepada mustahik (penerima zakat) ketika bisa obyektif menghitung besaran kewajiban zakatnya, disamping mereka dapat menilai siapa yang layak untuk menjadi mustahik zakat dari yang bersangkutan. Di pihak lain, zakat tersebut dapat diserahkan kepada amil (pengelola) zakat yang telah diangkat atas nama umara (penguasa) yang mempunyai kompetensi untuk melakukan perhitungan, pendistribusian, dan pendayagunaan secara kolektif dan bersifat kelembagaan di daerah yang menjadi wilayahnya kepada pihak mustahik yang layak dan pantas untuk menerima harta zakat itu. Peranan amil zakat itu begitu sangat strategis sekaligus meningkatkan optimalisasi keberadaannya menuju dinamika umat yang semakin sejahtera baik lahir maupun batin, akan semakin kuat iman dan akidahnya serta kehidupan ekonominya di tengah-tengah masyarakat.

\section{Hakikat Zakat}

Ditinjau dari segi bahasa, menurut lisan arab, kata zakat merupakan kata dasar (masdar) dari zakat yang berarti suci, berkah, tumbuh, dan terpuji, yang semua arti digunakan dalam menerjemahkan Alquran dan hadits. Menurut terminologi syariat (istilah), zakat adalah nama bagi sejumlah harta tertentu yang telah mencapai syarat tertentu yang diwajibkan oleh Allah untuk dikeluarkan dan diberikan kepada yang berhak menerimanya dengan persyaratan tertentu pula. Sedangkan dalam istilah ekonomi, zakat merupakan tindakan pemindahan kekayaan dari golongan kaya kepada golongan tidak punya. Zakat merupakan perintah agama yang wajib dilaksanakan oleh umat Islam yang mampu dalam melaksanakannya. Seperti yang terdapat pada QS. 2

\footnotetext{
${ }^{3}$ Alî Ahmad Al-Jurjânî, Hikmah at-Tasyrî̀wa Falsafatuhû, h. 44.
} 
Al Baqarah [2]: 43 sebagai berikut: "Dan dirikanlah shalat, tunaikanlah zakat dan ruku' lah beserta orang-orang yang ruku."

Zakat adalah ibadah "maaliyah ijtimaiyah" yang memiliki posisi dan peranan yang penting dan strategis, dari sudut keagamaan, sosial, ekonomi dan kesejahteraan masyarakat. Pemungutan dan penyaluran zakat kepada mustahik yang berhak menerimanya sejak dari masa Nabi Muhammad Saw, yang dilanjutkan dengan masa sahabat dan seterusnya, harus dilakukan melalui amil yang amanah (QS At Taubah ayat 60 dan 103).

Zakat merupakan salah satu kewajiban yang disyariatkan Allah kepada umat Islam, sebagai salah satu perbuatan ibadah setara dengan shalat, puasa dan ibadah haji. Akan tetapi, zakat tergolong ibadah maaliah, yakni ibadah melalui harta kekayaan dan bukan ibadah badaniah yang pelaksanaannya dengan fisik. Hal inilah yang membedakan zakat dengan ibadah ritual lainnya, seperti ibadah shalat, puasa, maupun haji, dimana manfaatnya hanya terkena kepada individu tersebut semata, sedangkan zakat manfaatnya bukan untuk individu tersebut semata, namun bermanfaat pula bagi orang lain.

Zakat merupakan institusional keuangan umat Islam yang menjadi sumber dalam menjamin keharmonisan sosial masyarakat, disamping infak, sedekah dan wakaf. Zakat bersumber dari harta yang jelas dan mempunyai sasaran yang jelas. Prinsip-prinsipnya telah diatur dalam Alquran dan Hadits. Sehingga, pengumpulan tidak dapat ditolak dan penggunaannya tidak dapat diselewengkan atau disalahgunakan. Pembantahan atau penolakan dan penyalahgunaan zakat, berarti pembangkangan dan pelanggaran terhadap perintah Allah. Atas dasar ini, maka kegiatan zakat dipastikan tetap berlangsung sepanjang Islam masih hidup di muka bumi ini. Manusia mempunyai fitrah ingin suci dan taat di mata Allah. Dengan demikian, zakat merupakan pendapatan tetap, dan karena itu, dapat menjadi pendapatan publik, di mana negara berhak dan berkewajiban untuk mengelola pendapatan tersebut menjadi pendapatan yang berguna bagi umat manusia.

Hak dan kewajiban ini sejalan pula dengan salah satu fungsi negara dalam Islam, yaitu untuk menjamin terpenuhnya kebutuhan hidup pokok rakyatnya. Dalam konsep ekonomi Islam, salah satu tugas baitulmal adalah menjalankan fungsi negara tersebut, yaitu dengan mengambil kekayaan dari kelompok muzakki, kemudian membaginya kepada kelompok mustahik. Mekanisme zakat memastikan aktifitas ekonomi dapat berjalan pada tingkat yang minimal yaitu pada tingkat pemenuhan kebutuhan primer. Namun, tidak menutup kemungkinan, jika dalam jumlah yang besar dapat mendorong permintaan secara agregat, karena dapat berfungsi membantu masyarakat, untuk mencapai taraf hidup di atas tingkat minimum. Dapat digunakan untuk

4 Allah mewajibkan zakat kepada individu yang mampu dengan tujuan untuk mengetahui seberapa besar cinta hamba kepada Penciptanya daripada dengan hartanya, sebab secara naluri alamiah manusia memiliki kecenderungan merasa sangat berat apabila harus berkorban dengan hartanya, sehingga dengan kewajiban zakat ini, akan mampu memperlihatkan sosok manusia beriman sejati apakah lebih sayang terhadap hartanya ataukah terhadap Penciptanya. 
mengentaskan kemiskinan melalui program-program pembangunan. Dengan demikian zakat memungkinkan perekonomian terus berjalan pada tingkat minimum, dan berpeluang untuk meningkatkan taraf hidup mustahik di atas tingkat minimum.

Zakat memiliki korelasi positif pada angka konsumsi yang akan menggerakkan perekonomian. Model konsumsi secara makro ditentukan oleh konsumsi pokok dan konsumsi yang berasal dari pendapatan. Jika dilihat dari sisi mustahik, maka zakat akan meningkatkan agregat konsumsi dasar, yaitu akumulasi konsumsi pokok. Hal ini secara logis terjadi akibat akomodasi sistem ekonomi terhadap pelaku pasar yang tidak memiliki daya beli atau mereka yang tidak memiliki akses pada ekonomi. Sehingga mereka memiliki daya beli yang memadai untuk memenuhi kebutuhan dasar. Kegiatan belanja (konsumsi) merupakan variabel yang sangat positif bagi kinerja perekonomian (economic growth). Ketika perekonomian mengalami stagnasi, seperti terjadi penurunan tingkat konsumsi, kebijakan utama yang diambil adalah bagaimana dapat menggerakkan ekonomi dengan meningkatkan daya beli masyarakat. Sehingga dapat dikatakan bahwa kemampuan daya beli masyarakat menjadi sasaran utama dari setiap kebijakan ekonomi. ${ }^{5}$ Dengan mekanisme zakat yang baik, peningkatan daya beli masyarakat tetap dapat stabil. Maka zakat memiliki peran yang cukup signifikan untuk menjaga kestabilan perekonomian.

\section{Peranan Strategis Amil Zakat}

Hadirnya kewajiban ibadah zakat merupakan sebuah solusi dan terobosan untuk mengatasi berbagai kesenjangan sosial yang telah melahirkan kemiskinan struktural. Serta mengikis ketamakan dan kebakhilan dan sikap egoistik para pemilik harta terhadap amanah rizki dan penghasilan yang didapat. Selain menjadikan hikmah dan manfaat bagi muzakki untuk semakin tumbuh dan subur harta yang dimiliki secara kualitatif dan kuantitatif. ${ }^{6}$

Kewajiban zakat telah dilaunching pada bulan Syawal tahun ke 2 Hijrah, pasca Rasulullah Saw dan para sahabatnya hijrah dari Mekah ke Madinah setelah menerima kewajiban puasa Ramadhan, dan dua tahun setelah diwajibkan pelaksanaan ibadah shalat. Juga, perintah mengeluarkan ibadah zakat ini umumnya disandingkan dan dipaketkan dengan perintah melaksanakan ibadah shalat sejumlah 82 kali dalam berbagai konteks dan kosakatanya. Hal tersebut menjadi indikator bahwa kesalihan seseorang bukan semata ditentukan oleh kesalihan komunikasi vertikalnya kepada Allah, akan tetapi kesalihan seseorang juga sangat ditentukan dengan kesalihan horizontal atau juga disebut dengan kesalihan sosialnya. ${ }^{7}$

5 Ali Sakti, Ekonomi Islam: Jawaban atas Kekacauan Ekonomi Modern (Jakarta: Paradigma dan Aqsa Publishing, 2007), h.55.

${ }^{6}$ Didin Hafidhuddin, Agar Harta Berkah dan Bertambah, Jakarta: Gema Insani, 2007, h. 68-9.

${ }^{7}$ Lihat: Sayyid Sabiq, dan Wahbah Zuhaili, al-fiqhul al-islami wa adillatuhu, (Bairut: Darul Kitab, Juz 2), h. 730-735. 
Kebijakan Rasulullah Saw dengan petunjuk wahyu Ilahi yang telah dapat mempersatukan masyarakat Mekkah (Muhajirin) dan Madinah (Anshar) yang memiliki karakter dan adat kebiasaan yang berbeda dengan mengusung masyarakat Madinah yang madani dan mandiri, juga diperkuat dengan nuansa keberjamaahan dan juga dibangkitkan semangat solidaritas sosial melalui media zakat, infak dan sedekah untuk menuju masyarakat yang solid dan bersatu (ummah wahidah) yang dibingkai dengan penuh rahmah dan kasih sayang, dan sejahtera di bawah Ridha Allah SWT. ${ }^{8}$

Dalam perspektif hukum Islam, harta yang dijadikan obyek zakat merujuk kepada mata pencaharian dan sumber kekayaan umat, yang klasifikasinya sebagai berikut: 1). Zakat binatang ternak (peternakan), 2). Zakat hasil pertanian (tanaman dan buahan), 3). Zakat emas dan perak, 4). Zakat perdagangan/perniagaan. 5). Zakat harta temuan/rikaz, dan 6). Zakat profesi/keahlian.

Pada prinsipnya, Muzakki dapat menditeksi dan menghitung langsung harta kekayaan yang menjadi obyek zakatnya dari berbagai aspeknya, kemudian mendistribusikannya kepada para mustahiq yang dianggap layak dan pantas untuk mendapatkannya. Hanya dalam pelaksanaannya butuh waktu untuk melakukannya, dan keseriusan secara obyektif untuk menghitungnya.

Dalam perspektif hukum Islam, pihak yang dapat memediasi secara profesional dan serius untuk mengurus, memanage, mengumpulkan, dan mendistribusikan zakat adalah Amil zakat. Allah SWT secara langsung sangat menghargai dan menempatkan peranan amil zakat pada tempat dan alokasi khusus secara proporsional yang mendapat backup dari harta zakat, dengan sebutan: "و العاملين عليها", dengan menggunakan isim jama` muzakkar salim (tidak menggunakan jama` taksir (العِّال) pegawai yang lebih kepada otot, dan dipilihkan kata depan "على" yang artinya: petugas atau pengelola yang mempunyai kompetensi, fokus dan profesional untuk mengurus zakat. Oleh sebab itu, Rasulullah, sebagai kepala pemerintahan, pernah mengangkat seorang amil zakat dari kalangan Bani Asad yang bernama Ibnu Luthaibah yang secara spesifik mengurus Bani Sulaim. Selain itu, Rasulullah SAW juga pernah mengangkat Ali bin Abi Thalib untuk ditugasi melakukan sosialisasi zakat dan bertindak sebagai amil zakat di Yaman, dan diteruskan oleh Mu’az bin Jabal melakukan da'wah zakat, selain juga Mu'az menjadi hakim di Yaman. ${ }^{9}$

${ }^{8}$ Kondisi masyarakat Madinah yang terdiri dari kalangan Muhajirin yang notabene tidak membawa banyak harta kecuali membawa semangat iman dan kompetensi mereka dalam bidang agama (terutama membaca dan menulis Alquran), karena telah dibina Rasulullah selama 10 tahun, selain sebagian hartanya ditinggalkan di kota kelahirannya Mekah. Demikian juga kalangan Anshar, umumnya aktifitas mereka dalam bidang perdagangan, peternakan, dan pertanian, menjadikan kekuatan ekonomi untuk membantu kalangan Muhajirin dengan terbangunnya semangat persaudaraan (Muakhah), hal tersebut banyak dilakukan khususnya tampil sebagai dermawan dari seorang sahabat kalangan Anshar adalah Usman bin `Affan.

9 Wahbah Zuhaili, al-fiqhul al-islami wa adillatuhu, (Bairut: Darul Kitab, Juz 2), h. 730-735. 


\section{Peran Pemerintah Sebagai Amil}

Posisi pemerintah adalah sebagai 'amil (pengelola zakat). Baik bekerja langsung atau tidak langsung, yaitu dengan menunjuk lembaga sebagai pengelola, tetap saja pemerintah yang bertanggung jawab atas pelaksanaan zakat. Hal ini jelas disebutkan dalam Alquran surat at-Taubah ayat 60 dan 103.

Pengelola zakat sebagai salah satu golongan yang berhak menerima zakat yang ditentukan Allah dalam Alquran, bukanlah tanpa maksud. Penyebutan posisi ini dalam Alquran mengisyaratkan bahwa Tuhan menginginkan adanya pengelolaan dana zakat yang profesional oleh institusi atau lembaga yang disebut 'amil. Mereka inilah yang melakukan upaya pengumpulan, sekaligus mengelola dan mendistribusikannya untuk kepentingan tujuan zakat. Untuk kerja inilah mereka berhak mendapat sebagian dana zakat, dan karena itu nama mereka disebut dalam Alquran. Konsekuensinya, lembaga atau orang yang mengatasnamakan 'amil namun tidak mengeluarkan daya upaya untuk mengumpulkan, mengelola dan mendistribusikan zakat secara profesional, maka mereka haram mendapatkan porsi dana zakat. 'Amil semacam ini justru menggerogoti spirit keadilan sosial dan ekonomi dalam zakat.

Agar tidak terjadi hal demikian, maka peran pemerintah harus dioptimalkan. Pemerintah seharusnya tidak ragu-ragu untuk mengambil kebijakan tentang zakat, karena 'amil (lembaga zakat) itu sungguh akan menjadi tiang agama sekaligus tiang ekonomi dari semua ummat manusia, di semua dimensi ruang dan waktu. Apalagi negara memang bertugas dan bertanggung jawab terhadap kemakmuran dan kesejahteraan rakyatnya. Dengan optimalnya peran pemerintah dalam kebijakan zakat, diharapkan dapat mempermudah dan membantu tugas-tugas pemerintah itu sendiri.

Tanggung jawab dan kewajiban pemerintah dalam mengelola zakat tersurat dalam firman Allah SWT dalam surat al-Taubah (9): 103. ${ }^{10}$ Dalam ayat ini, Allah SWT memerintahkan kepada Rasulullah untuk mengambil harta dari pemiliknya sebagai sedekah ataupun zakat. ${ }^{11}$ Dijelaskan dalam tafsir Depertemen Agama RI jilid IV, bahwa menurut riwayat Ibnu Jarir, ayat ini diturunkan sehubungan dengan peristiwa Abu Lubabah dan kawan-kawannya yang mengikatkan diri di tiang-tiang masjid datang kepada Rasulullah Saw seraya berkata: "Ya Rasulullah, inilah harta benda kami yang merintangi kami untuk turut berperang. Ambillah harta itu dan bagi-bagikanlah, serta mohonkanlah ampun untuk kami atas kesalahan kami. Rasulullah menjawab: Aku belum diperintahkan untuk menerima hartamu itu, maka turunlah ayat

${ }^{10}$ Ambillah (himpunlah, kelola) dari sebagian harta mereka sedekah/zakat; dengan sedekah itu kamu membersihkan mereka dan mensucikan mereka, dan berdoalah untuk mereka, karena sesungguhnya doa kamu itu menjadi ketentraman jiwa bagi mereka; dan Allah Maha Mendengar lagi Maha Mengetahui".

${ }^{11}$ Dalam hadis lain dikatakan: "Aku diperintahkan untuk memerangi manusia hingga mereka bersaksi bahwa tidak ada Tuhan selain Allah dan bahwa Muhammad adalah Rasulullah, menegakkan shalat, menunaikan zakat. Jika mereka melakukan hal itu maka darah dan harta mereka akan dilindungi kecuali dengan hak Islam dan perhitungan mereka ada pada Allah Subhanahu wata'ala." (Riwayat Bukhari No. 2946 dan Muslim No. 21) 
ini”. Dan dijelaskan pula bahwa walaupun perintah memungut zakat dalam ayat ini, pada awalnya adalah ditujukan kepada Rasulullah, namun ia juga berlaku terhadap semua pemimpin atau penguasa dalam setiap masyarakat kaum muslimin, agar zakat dapat memenuhi fungsinya sebagai sarana yang efektif untuk membina kesejahteraan masyarakat.

Adanya keikhlasan dari orang yang punya harta untuk menyerahkan bagian zakatnya kepada Rasulullah menunjukkan bahwa pemerintah dapat bersifat pasif (menunggu), karena ada kesadaran dari pihak yang mempunyai harta (muzakki). Namun, jika yang mempunyai harta tidak membayar zakatnya secara sukarela, dengan kata lain tidak mau membayar zakatnya, atau karena keterbatasan pengetahuannya tentang zakat menjadi tidak membayar zakat, maka dalam situasi ini pemerintah yang wajib bersifat aktif dan memungut zakatnya.

Rasulullah Saw pernah mengutus Umar r.a dan Mu'az bin Jabal untuk memungut dan membagikan zakat kepada mereka yang berhak. Rasulullah juga mengangkat pegawai zakat, yaitu Ibn Lutabiyah, Abu Mas'ud, Abu Jahm, 'Uqbah bin Amir, Dahhâq Ibn Qais dan 'Ubadah Ibn Samit. Selanjutnya alkhulafâ'u ar-râsyidîn pun berbuat demikian. Mereka mengeluarkan kebijaksanaan yang mengarahkan bahwa negara atau pemerintah sebagai lembaga yang berwenang mengurusi urusan zakat. Abu Bakar Shiddiq (dengan menggunakan segala kekuasaan pemerintah) memerangi mereka yang tidak mau membayar zakat walaupun mereka menegakkan shalat. Abu Bakar berkata: "Demi Allah, pastilah aku perangi siapa saja yang memisahkan antara shalat dan zakat, karena zakat itu adalah hak (kewajiban) harta. ${ }^{12}$ Demi Allah apabila mereka menghalangi aku mengambil zakat, walaupun seekor kambing sebagaimana mereka telah menyerahkannya kepada Rasulullah Saw, niscaya aku perangi mereka karenanya." ${ }^{13}$ Artinya pemerintah dapat bersifat aktif bahkan boleh memaksa orang-orang yang tidak membayar zakat dengan alasan tertentu. Peran ini dapat dilakukan secara bersama-sama, 'amil, muzakki dan masyarakat pada umumnya.

Alasan, bahwa Indonesia bukan Negara Islam, sehingga pemerintahnya tidak dapat ikut campur terlalu jauh dalam hal zakat, adalah alasan yang terlalu dibuat-buat dan dapat menyesatkan. Karena diketahui bahwa saat penerapan dan penegakan hukum zakat oleh Rasulullah dan Abu Bakar, tidak semua masyarakat saat itu beragama Islam. Hukum zakat pun tidak diberlakukan bagi non Muslim. Saat ini, yang penting adalah mau atau tidak, berani atau tidak. Di sinilah pentingnya peran lain (pendamping) yaitu para kiyai, dai dan daiyah, dan masyarakat untuk mendukung dan ikut serta dalam membangun zakat, bersama dengan para muzakki, mustahik dan pemerintah. Saling bahumembahu, karena tugas ini adalah tugas berat yang tidak dapat dilakukan oleh orang perorang atau satu lembaga saja.

\footnotetext{
${ }^{12}$ Lihat: Syekh Abdurrahman al-Jaziri, kitab al-Fiqh 'ala madzahibil 'Arba'a, (Beirut: Daar Ihya Turats al-Arabi, 1998), Juz 1, h.515-517.

${ }^{13}$ Riwayat Bukhari No. 1400 dan Muslim No. 20.
} 
Semuanya bekerja dalam satu sistem, dalam pengembangan masyarakat miskin berbasis pada dana zakat. Dana tanpa bunga, barakah dan aman. Untuk itu yang paling penting adalah semua harus memiliki komitmen yang sama, bahwa zakat akan berdampak, baik pada perekonomian sebuah bangsa. Artinya jika negara berminat dan berusaha untuk mengelola zakat secara profesionalmodern, jujur dan terpercaya, maka semua pihak, muzakki, mustahik, para ulama dan masyarakat harus mendukung usaha tersebut. Tanpa adanya kesepakatan, maka usaha apa pun yang dilakukan tidak bisa berjalan dengan baik. Selain itu, semua pihak juga harus mengawasi dan mengevaluasi kinerja pemerintah tersebut.

\section{Implementasi Undang-Undang Nomor 23 Tahun 2011 Terhadap Legalitas Pengelolaan Zakat}

Pengelolaan zakat awalnya pada masa penjajahan dan kemerdekaan memiliki gambaran buram tentang fungsi zakat, karena tidak ada pembayaran dan penyaluran zakat secara baik, sehingga pada masa orde baru pemerintah mengeluarkan UU No. 38/1999 tentang pengelolaan zakat dalam rangka melembagakan pengelolaan zakat. Hal ini bertujuan agar mempermudah dalam pengelolaan zakat, sehingga menunjang kebutuhan sosial untuk konsumtif maupun produktif serta merupakan awal dari terbukanya keterlibatan publik secara aktif melalui BAZ (Badan Amil Zakat). Namun UU No. 38/1999 tentang pengelolaan zakat dianggap belum mampu menjawab permasalahan pengelolaan tersebut, sehingga pemerintah merevisi UU No. 38/1999 menjadi UU No. 23/2011 tentang pengelolaan zakat agar dapat memperbaiki undangundang sebelumnya. Karena UU No. 38/1999 sudah tidak sesuai dengan perkembangan kebutuhan hukum dalam masyarakat. Pengelolaan zakat di Indonesia untuk saat ini, telah diatur oleh UU No. 23/2011.

Berdasarkan undang-undang tersebut dijelaskan mengenai dana zakat yang dapat disalurkan melalui BAZ yang merupakan organisasi bentukan pemerintah dan LAZ bentukan non-pemerintah. ${ }^{14}$ UU No. 23/2011 dibuat

${ }^{14}$ Pada dasarnya Direktorat Jenderal Pajak telah menetapkan 20 Badan/Lembaga sebagai penerima zakat atau sumbangan Keagamaan yang sifatnya wajib. Zakat atau sumbangan keagamaan ini dapat dikurangkan dari penghasilan bruto. Hal ini diatur dalam Peraturan Direktur Jenderal Pajak Nomor PER-33/PJ/2011 yang berlaku sejak tanggal 11 November 2011. Badan/Lembaga yang ditetapkan sebagai penerima zakat atau sumbangan meliputi satu Badan Amil Zakat Nasional, 15 Lembaga Amil Zakat (LAZ), 3 Lembaga Amil Zakat, Infaq, dan Shaaqah (LAZIS) dan 1 Lembaga Sumbangan Agama Kristen Indonesia. Ke-20 Badan/Lembaga penerima zakat atau sumbangan itu adalah sebagai berikut: 1). Badan Amil Zakat Nasional, 2). LAZ Dompet Dhuafa Republika, 3). LAZ Yayasan Amanah Takaful, 4). LAZ Pos Keadilan Peduli Umat, 5). LAZ Yayasan Baitulmaal Muamalat, 6). LAZ Yayasan Dana Sosial Al Falah, 7). LAZ Baitul Maal Hidayatullah, 8). LAZ Persatuan Islam, 9). LAZ Yayasan Baitul Mal Umat Islam PT Bank Negara Indonesia, 10). LAZ Yayasan Bangun Sejahtera Mitra Umat, 11). LAZ Dewan Da'wah Islamiyah Indonesia, 12). LAZ Yayasan Baitul Maal Bank Rakyat Indonesia, 13). LAZ Yayasan Baitul Maal wat Tamwil, 14). LAZ Baituzzakah Pertamina, 15). LAZ Dompet Peduli Umat Daarut Tauhiid (DUDT), 16). LAZ Yayasan Rumah Zakat Indonesia, 17). LAZIS Muhammadiyah, 18). LAZIS Nahdlatul Ulama (LAZIS NU), 19). LAZIS Ikatan Persaudaraan Haji Indonesia (LAZIS IPHI), 20). Lembaga Sumbangan Agama Kristen Indonesia (LEMSAKTI). 
dalam rangka meningkatkan daya guna dan hasil guna, zakat harus dikelola secara melembaga sesuai dengan syariat agama Islam yang bertujuan melakukan pengelolaan zakat. Pengelolaan yang dimaksud meliputi kegiatan perencanaan, pelaksanaan, dan pengordinasian dalam pengumpulan, pendistribusian, dan pendayagunaan zakat.

Namun dalam implementasinya UU No. 23/2011 mengalami banyak kontroversi karena dianggap mempersulit masyarakat dalam mengumpulkan zakat dan menyalurkan kembali kepada masyarakat. Pada UU No. 23/2011 terdapat pasal krusial yang menyalahi norma dalam masyarakat, UU No. 23/2011 dapat mengerdilkan peran mandiri masyarakat dalam memberdayakan dana zakat. Selain itu, hasil revisi UU zakat tersebut, telah menghambat kinerja dan menghambat peran lembaga-lembaga zakat yang telah ada. Disyahkannya UU No. 23/2011 tentang pengelolaan zakat dinilai belum sepenuhnya sesuai dengan kebutuhan dan belum menjawab permasalahan perzakatan yang ada karena, di dalam UU tersebut terdapat pasal yang multitafsir yang dapat menimbulkan pro dan kontra di kalangan pegiat zakat.

UU No. 23/2011 dimaksudkan untuk memastikan keteraturan dan akuntabilitas dalam perencanaan pengumpulan, pendistribusian, dan pendayagunaan zakat; pelaksanaan pengumpulan, pendistribusian, dan pendayagunaan zakat; dan pelaporan dan pertanggungjawaban pelaksanaan pengelolaan zakat. Akan tetapi adanya krisis kepercayaan masyarakat pada kinerja pemerintah merupakan salah satu alasan mengapa banyak kontroversi mengenai pengelolaan zakat yang langsung ditangani pemerintah, karena dikhawatirkan akan muncul peluang timbulnya korupsi dan ketidakmerataan pendistribusian zakat.

Sikap tradisional masyarakat juga mempengaruhi terhambatnya pengaplikasian UU No. 23/2011, karena para pemberi zakat lebih mempercayakan penyaluran kepada masjid terdekat atau lembaga lembaga penyalur lainnya yang ada di daerahnya, yang setiap tahun melakukan pengumpulan dan penyaluran zakat. Penyaluran zakat melalui masjid didasari kepraktisan dan kedekatan lokasi.

Alasan lain mengapa masyarakat tidak mempercayai lembaga yang dibentuk pemerintah diakibatkan sistem birokasi dan good governance yang masih lemah didukung pula dengan tingkat korupsi yang sangat tinggi di Indonesia, sehingga dikhawatirkan zakat yang merupakan salah satu wujud ketaatan agama akan disalahgunakan oleh pemerintah untuk kepentingan politis dan tidak sesuai dengan tujuan UU No. 23/2011. Selain itu dalam UU No. 23/2011 terdapat pasal-pasal yang tidak berkesinambungan dengan kondisi masyarakat dan menghambat kinerja pendistribusian zakat dari lembaga penyaluran zakat yang selama bertahun-tahun melaksanakan penyaluran zakat karena kurang mendapat jaminan dan pelindungan hukum yang memadai dalam UU No. 23/2011.

\section{Implikasi Optimalisasi Peran Amil Zakat}

Implementasi sistem zakat akan dapat mengurangi kemiskinan dan pengangguran yang menjadi penyakit dalam pembangunan perekonomian 
suatu wilayah. Implementasi pengembangan ekonomi zakat membutuhkan keterlibatan pemerintah, muzakki dan mustahik. Semua pihak harus peduli dan bekerja keras dalam mewujudkannya. Jika tidak, berarti sama saja dengan membiarkan ketidakadilan ekonomi terjadi. Pengelolaan secara profesional dapat meningkatkan kesadaran muzakki dalam penunaian zakat. Karena masih ada umat Islam yang kaya (mampu) belum menunaikan ibadah zakatnya, bukan karena persoalan kemampuan, akan tetapi karena kurangnya pengetahuan dan kesadaran berzakat.

Penunaian zakat akan membangkitkan solidaritas sosial, mengurangi kesenjangan sosial dan pada gilirannya akan mengurangi derajat kejahatan di tengah masyarakat. Untuk ini, pemerintah, BAZ atau LAZ harus memiliki database mengenai muzakki dan mustahik di wilayah kedudukannya. Peta muzakki dan mustahik diperlukan untuk melakukan sosialisasi dan pembinaan, guna memupuk kepercayaan para muzakki, mustahik, dan masyarakat pada umumnya terhadap pengelolaan zakat oleh Negara atau lembaga zakat.

Zakat yang sudah mengakar dalam sanubari masyarakat muslim merupakan potensi besar dalam mengembangkan ekonomi masyarakat lemah. Semua pihak mulai dari yang wajib zakat (muzakki), yang menerima zakat (mustahik), pemerintah sebagai pengelola zakat dan ulama sebagai pakar agama sampai pada masyarakat secara luas secara bersama-sama wajib memaksimalkan fungsinya masing-masing dalam pengelolaan zakat. Ajaran Islam tentang zakat menunjukkan bahwa persoalan kemiskinan dan zakat ibarat dua sisi mata uang. Tidak bisa dipisahkan, karena zakat memiliki pengaruh-pengaruh yang baik dan positif pada aspek sosial-ekonomi, memberikan dampak terciptanya keamanan masyarakat dan menghilangkan pertentangan kelas karena ketajaman perbedaan pendapatan.

\section{Penutup}

Pelaksanaan zakat oleh negara tentunya akan menunjang terbentuknya keadaan ekonomi yang growth with equity. Peningkatan produktivitas yang dibarengi dengan pemerataan pendapatan serta peningkatan lapangan pekerjaan bagi masyarakat. Dana zakat sangat berpotensi sebagai sumber pembelanjaan bagi masyarakat muslim dan sumber daya untuk mengatasi berbagai macam social cost yang diakibatkan dari hubungan antar manusia. Sistem zakat mampu membangun pertumbuhan ekonomi sekaligus pemerataan incame economic growth with equity. Mampu mencegah praktek riba, mampu menjadi jaminan sosial dan dapat mengangkat ekonomi rakyat lemah.

\section{Pustaka Acuan}

Alî Ahmad Al-Jurjânî, Hikmah at-Tasyrî̀wa Falsafatuhû, (Singapura : alHaramain, t.th.)

Ahmad Muhammad al-Hasri, Tafsîr Âyât Al-Ahkâm (Beirut :Dâr al-Qalam, t.th).

Ali Sakti, Ekonomi Islam: Jawaban atas Kekacauan Ekonomi Modern (Jakarta: Paradigma dan Aqsa Publishing, 2007). 
Didin Hafidhuddin, Agar Harta Berkah dan Bertambah, Jakarta: Gema Insani, 2007.

Sayyid Sabiq, dan Wahbah Zuhaili, al-fiqhul al-islami wa adillatuhu, (Bairut: Darul Kitab, Juz 2).

Wahbah Zuhaili, al-fiqhul al-islami wa adillatuhu, (Bairut: Darul Kitab, Juz 2). Syekh Abdurrahman al-Jaziri, kitab al-Fiqh 'ala madzahibil 'Arba'a, (Beirut: Daar Ihya Turats al-Arabi, 1998), Juz 1. 